International Journal of Life Sciences
Available online at http://sciencescholar.us/journal/index.php/ijls
Vol. 2 No. 3, December 2018, pages: 142 150
e-ISSN: 2550-6986, p-ISSN: 2550-6994
https://doi.org/10.29332/ijls.v2n3.234

\title{
Utilization Burning Rice Straw and Crops Planted
}

\author{
(1) cossinat \\ I Nengah Muliarta ${ }^{a}$
}

Article history: Received 27 July 2018, Accepted: 30 August 2018, Published: 17 December 2018

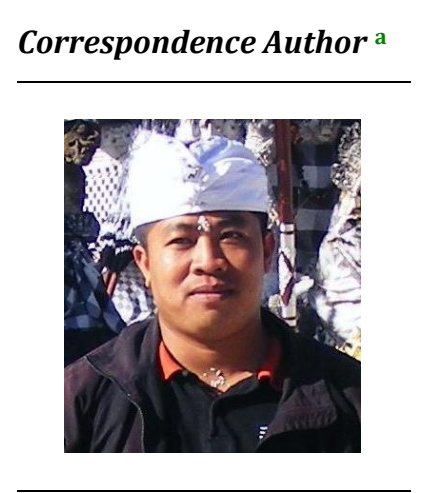

Keywords

burning;

crops;

harvesting;

planting season;

rice straw;

\section{Abstract}

The practice of burning rice straw after harvest seems to be normal and natural. The reason was simple to speed up the processing of land to pursue the next planting season and avoid the spread of pests and diseases. Whereas, rice straw open burning, aside from disposing of fertilizer resources was also a source of carbon gas emissions that have an impact on air quality. Rice straw burning has been closely related to the crops types that will be planted next. Data collected in the study were analyzed descriptively. The collected data were tabulated and presented in the form of frequency tables and percentages. Based on the study results, it was found that the type of crops to be planted greatly influenced the farmer's decision to burn rice straw. There were two types of plants that tend to influence the farmer's decision to burn rice straw, namely corn, and peanuts. Burning was also conducted if the farmers will return to planting rice after harvesting rice. They believe that the burning ash of rice straw will increase production from corn and peanuts.

e-ISSN: 2550-6986, p-ISSN: 2550-6994@ Copyright 2018. The Author. SS Journals Published by Universidad Técnica de Manabí. This is an open-access article under the CC BY-SA 4.0 license (https://creativecommons.org/licenses/by-sa/4.0/) All rights reserved.

\section{Contents}

Abstract

1. Introduction.

2. Materials and Methods. 143

3. Results and Discussions 144

4. Conclusion. 147

Acknowledgements.... 147

References. 148

Biography of Authors. 150

\footnotetext{
a Industrial Engineering Studies Program, Universitas Mahendradatta, Denpasar, Indonesia
} 


\section{Introduction}

The burning of rice straw by farmers generally aims to accelerate the processing of soil to pursue the next planting period. The burning of rice straw in several areas aims to avoid the spread of pests and diseases not to spread (Rosmiza et al., 2014a). The practice of open burning of straw has proven to be a significant source of carbon emissions during the harvest season. Open burning of straw significantly has also affected air quality (Chang et al., 2013). Burning rice straw not only causes air pollution but also impacts on public health and climate change (Tipayarom \& Oanh, 2007). Rice straw management is needed to avoid burning in order to obtain economic and environmental benefits (Kanokkanjana \& Garivait, 2013).

Burning rice straw causes almost all $(\mathrm{N})$ element loss, (P) element loss about 25\%, (K) elemental loss reaches $20 \%$ and (S) element from loss $5 \%$ to $60 \%$. The number of nutrients lost depends on the method used to burn rice straw (Dobermann \& Fairhurst, 2002). Nutrient loss is caused by scattering so that particles of ash and charcoal are carried away by the wind and washed away by rainwater. Losing these nutrients, the nutrient needs the soil must be compensated through fertilization (Malhi \& Kutcher, 2007).

According to Gupta (2012), the plant type's varieties and machinery used in production also have a significant impact on the choice of farmers to burn or not burn agricultural residues. Especially, the tropical regions such as in Indonesia, it is necessary to identify the types of secondary crops planted by farmers, causing farmers to choose to burn the rice straw produced. An identification is important to make a management plan for the rice straw use so that it is not wasted. The reason for the farmers burning rice straw produced also needs to be revealed in order to find a solution, therefore, pollution from burning rice straw can be reduced and as an effort from climate change mitigation from the agricultural sector.

\section{Materials and Methods}

This is a combination research of survey and observation. The survey was conducted from $9^{\text {th }}$ May to $10^{\text {th }}$ August 2017, three sub-districts in Klungkung Regency included Banjarangkan, Klungkung, and Dawan. Klungkung area was an option because Klungkung included in the national program for the development of rice, corn, and soybean. In each sub-district, two Subak groups were randomly selected and the number of respondents was 10 percent of each member of the Subak group (Arikunto, 2010). Subak group is the research sample presented in Table 1.

Table 1

The Subak group is the research sample

\begin{tabular}{llll}
\hline \multirow{2}{*}{ Sub-district } & Subak & $\begin{array}{l}\text { Total of } \\
\text { Farmers }\end{array}$ & $\begin{array}{l}\text { Total of Respondents } \\
(10 \%)\end{array}$ \\
\hline \multirow{2}{*}{ Banjarangkan } & Tegehan & 157 & 16 \\
& Lepang & 154 & 15 \\
\hline \multirow{2}{*}{ Klungkung } & Gembalan & 170 & 17 \\
& Jero Kuta & 110 & 11 \\
\multirow{2}{*}{ Dawan } & Pesinggahan & 186 & 19 \\
& Sampalan Dlod Margi & 110 & 11 \\
\hline \multicolumn{2}{l}{ Total of Respondents } & 887 & 89 \\
\hline
\end{tabular}

Before the questionnaire was used, the validity test and reliability test had been done first. It was done using Microsoft Excel 2010 software. The results of the validity test with a significance level or alpha of $0.05 \%$ indicate that of the 15 questions, there are nine questions declared valid. The questions are declared valid have $t$-count between 2.131 to 6.978 , while the $t$-table is 1.796 . Reliability test results show the reliability $t$-value is 0.845 or is above 0.60 , thus, the instrument can be stated to be reliable.

Muliarta, I. N. (2018). Utilization burning rice straw and crops planted. International Journal of Life Sciences, 2(3), 142-150. https://doi.org/10.29332/ijls.v2n3.234 


\section{Results and Discussions}

Data collected in the study were analyzed descriptively. The data collection is tabulated and presented in the form of frequency tables and percentages. The data obtained is processed using Microsoft Excel 2010 software.

Results

Farmers Characteristics in Klungkung Regency

The gender of farmers in Klungkung Regency is dominated by men i.e., 89 respondents $98.9 \%$ male farmers and only $1.1 \%$ ( 1 person) are female farmers. The dominance of male farmers also occurs in the Philippines which reaches $92 \%$ and in Vietnam reaches $85 \%$. This dominance shows that male farmers are responsible for lowland rice cultivation in the Philippines and Vietnam (Truc et al., 2012). Female farmers have limited access to funding, knowledge, and production resources. Female farmers are very strongly influenced by homework, thus, limiting performance in agriculture (Adewuyi \& Adebayo, 2014). Women are more involved in household responsibilities unlike caring for children and looking after homes, so time is limited in the involvement of rice production (Ayala-Zavala et al., 2011). The low number of women directly involved in agriculture also occurs in Borno-Nigeria which only reaches $1.88 \%$ and one of them is caused by cultural factors (Mustapha et al., 2012).

The age of farmers is very influential in determining the success of a farm, due to the older the rice farmers, the less enthusiasm for farming (Ayala-Zavala et al., 2011). The farmer's age description is presented fully in Figure 1.

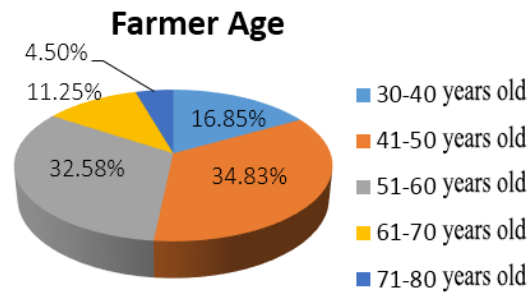

Figure 1. The farmer's age description

The age of the farmers in Klungkung Regency is 34.83\%, range 41-50 years old and 32.58\% range 51-60 years old. This data illustrates that the respondent's majority is still energetic and in productive age. There are only $11.25 \%$ of the farmers $60-70$ years old and $4.50 \%$ range $71-80$ years old. This result is almost the same as the research results in India, wherein most farmers (56.67\%) were in middle age and young age 16.67\% (Sharma et al., 2015). In a study in Borno-Nigeria, the farmer's majority were range 41-50 year old (Mustapha et al., 2012). The respondents who have been 61-70 years old and 71-80 claim to continue to do farming activities only to fill their spare time in their old time and farming activities are also used as a means of sports activities. Therefore, the body keeps healthy.

\section{Burning rice straw}

There are around $30.34 \%$ (27 farmers) who burn rice straw which is produced for reasons such as to speed up processing of land and discuss pests. There are also farmers who burn straw based on the knowledge obtained that burning ash of rice straw can be beneficial for soil fertility. Burning rice straw is one of the early applications of organic farming from the farmer's experience (Dobermann \& Fairhurst, 2002). Though burning straw is very ineffective because it can damage soil structure and reduce soil microbial activity. Burning rice straw can lose N (up to 80\%), P (25\%), K (21\%) and S (4-60\%) and loss of soil organic matter (Mandal et al., 2004). Some farmers also believe that burning open rice straw can eliminate weeds, control disease, and release nutrients for subsequent crops (Gadde et al., 2009). Burning straw also makes it easier to plow land and level the land which saves time for land management for the next planting season 
(Silalertruksa \& Gheewala, 2013). According to Gupta (2012), the varieties of plants and machinery used in production also have a significant impact on the farmer.s choice to burn or not burn agricultural residues. The research in Taiwan using remote sensing showed that there was open burning of rice straw around $27.3 \%$ of the existing paddy fields (Chang et al., 2013).

The farmer's habit burning rice straw is also related to the types of secondary crops planted after the rice harvest. They tend to burn rice straw if they plant crops included corn, peanuts, or plant rice again. It was revealed that from $30.34 \%$ (27 farmers) who burned rice straw, it was recorded that $40.74 \%$ (11 farmers) planted maize and $7.41 \%$ (2 farmers) left their land empty or not utilized. The description of the burning rice straw and the types of plants planted after the rice harvest are presented in Figure 2.

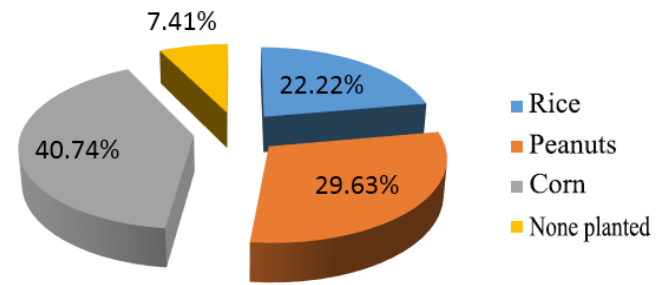

Figure 2. The tendency of the crops types planted by the farmers after burning rice straw

The farmers assume the ash from burning rice straw can increase the production of corn and peanuts. This view is in accordance with Ahmed et al., (2013), viewed stated that many farmers think that combustion residues improve soil health and yields. The farmer's technical capabilities do not seem to have an impact on the decision to burn rice residues. These results have important implications for mitigation policies to reduce residual combustion (Gupta, 2010). Some photographic evidence of burning rice straw by farmers in Klungkung Regency is presented in Figure 3.

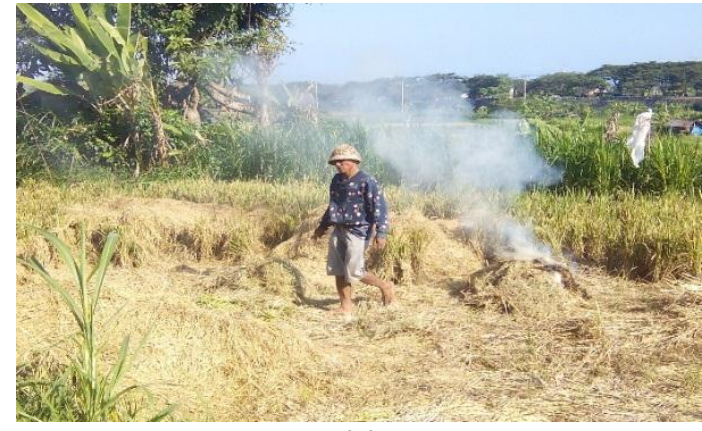

(a)

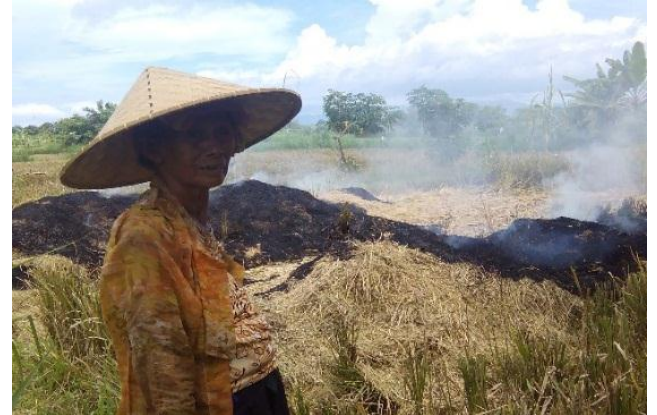

(b)

Figure 3. Burning rice straw in Klungkung Regency, (a) Location of Subak Dawan, (b) Location of Subak Sampalan Kelod

The Farmers in the Philippines burn about $90 \%$ of the total rice straw during the dry season harvest and $60 \%$ during the wet season (Mendoza \& Samson, 1999). The awareness and understanding of farmers about the importance of the role of organic matter in paddy fields are still low, as indicated the lack of farmer's attention in returning harvest waste to the soil. Rice straw is often burned, or allowed to be taken by people as fuel or for industrial use (Sumarno et al., 2009). Straw burning will have an impact on the death of microbes that are useful in biological processes, i.e., organic material decomposers, nitrogen binders, and microbes that have other biological functions (Tung et al., 2014). 


\section{Utilization of Rice Straw as Animal Feed and Mulch}

The survey was conducted, there were no farmers who used rice straw as animal feed, one reason being that $33.71 \%$ of farmers did not have cattle. Other farmers claimed not every rice harvest used rice straw as feed and tended to use it as feed when the rice harvest was done early plant not too old. Utilization as a feed is also carried out a very small number, due to the number of livestock owned, wherein $24.72 \%$ farmers only have 1 cow and $27.00 \%$ have 2 cattle. Farmers reasoning that rice straw feed is not good for animal health and forage feed in the Klungkung region is always available every year. According to Trach (1998), the amount of rice straw can be consumed by livestock is not enough to maintain production levels due to low nutritional value. Low nutritional value is low protein and nutritional content. The low content of straw protein can be seen from the results of laboratory tests of Ciherang varieties of rice straw taken from Subak Gelgel area, Klungkung Regency, Bali as presented in Table 2.

Table 2

The content of rice straw fiber

\begin{tabular}{lll}
\hline No & Parameter & Content \\
\hline 1. & Water content & $73,06 \%$ \\
2. & Ash content & $5,09 \%$ \\
3. & Protein & $2,72 \%$ \\
4. & Fat level & $0,38 \%$ \\
5. & Carbohydrate & $17,93 \%$ \\
6. & Rough Fiber & $7.72 \%$ \\
\hline
\end{tabular}

The content of lignin and silica in rice straw limits the digestibility of livestock (Oladosu et al., 2016), and lignin on plant cell walls limits the ability of rumen microbes to degrade rice straw (Wang \& McAllister, 2002). The results of laboratory tests on the lignocellulose content of rice straw are presented in Table 3.

Table 3

Lignocellulose content of rice straw

\begin{tabular}{lll}
\hline No & Parameter & Content \\
\hline 1. & Cellulose & $30,47 \%$ \\
2. & Hemicellulose & $18,16 \%$ \\
3. & Lignin & $21,60 \%$ \\
4. & Silica & $16,60 \%$ \\
5. & Phenol & $7,73 \mathrm{mg} / 100 \mathrm{gr} \mathrm{GAE}$ \\
\hline
\end{tabular}

The farmer's dominant in Klungkung Regency (69.66\%) use rice straw as mulch, especially when farmers plant crops. Rice mulch is needed when planting crops e.g., soybeans, chili, long beans, cucumber, watermelon, flowers, and green vegetables. This result is similar to Rosmiza et al., (2014b) statement stated that rice straw is generally used as mulch when growing vegetables and horticulture. The use of rice straw mulch is carried out for several reasons such as to suppress the growth of disturbing plants, reduce evaporation and reduce the cost of purchasing plastic mulch. The reason for the farmers is in accordance with Coolong (2012), viewed that rice straw mulch is useful for weed control and can reduce production costs. According to Eusufzai et al., (2007), rice straw mulch minimizes soil shrinkage by reducing evaporation from the soil surface. Rice straw can reduce soil density and increase water absorption, increase porosity and decrease bulk density.

Based on the survey results, it was also revealed that there were no farmers who made rice straw. They are reluctant to immerse rice straw produced due to fresh rice straw after harvesting makes it difficult when processing land. Straw immersion also has an itchy effect on the skin when processing land. Decomposition of organic matter in the early stages produces organic acids i.e., oxalic acid, formic and maleic acid (Kumari et al., 2008). As one organic acid, oxalic acid can have a negative effect on the skin in the form of skin and eye irritation (Dakshene et al., 2013). 


\section{Conclusion}

The conclusions that can be drawn from this study included (1) types of crops grown after the rice harvest affect farmer's decision to burn rice straw. (2) The farmers tend to burn rice straw after harvest if during the next planting period they will plant corn or peanuts. (3) The farmers tend to burn rice straw if they are going to plant corn or peanuts in the next planting season. It is based on the knowledge obtained from generation to generation that rice straw ash can increase corn yields of peanut funds. Based on the study results, further research is needed to determine the effect of giving rice straw ash to the yields of corn and peanuts. It is also necessary to socialize that burning straw means removing fertilizer resources and burning rice straw will contribute to global warming.

\section{Data availability}

The figures and tables used to support the findings of this study are included within the article.

\section{Conflicts of interest}

The author declared that he has no conflicts of interest.

\section{Acknowledgments}

The author would like to thank the Klungkung District Agriculture Service for giving permission to conduct research. Acknowledgments are also conveyed to PPL Subak Sampalan Dlod Margi Dawan, PPL Subak Gembalan-Klungkung and PPL Subak Tegehan-Banjarangkan who have helped the authors establish communication with Subak group. The author also expressed his gratitude to Kelian Subak Pesinggahan Dawan Subak, Kelian Subak Gembalan Klungkung and Kelian Subak Tegehan Banjarangkan who had helped during the interview with farmers. 


\section{References}

Adewuyi, A. K., \& Adebayo, E. F. (2014). Profitability Differentials of Rice Production by Male and Female Farmers in Adamawa State. Nigeria Journal of Agricultural Economics, Extension and Rural Development: Spring Journal, 2(9), 164-69.

Ahmed, T., Ahmad, B., \& Ahmad, W. (2015). Why do farmers burn rice residue? Examining farmers' choices in Punjab, Pakistan. Land Use Policy, 47, 448-458. https://doi.org/10.1016/j.landusepol.2015.05.004

Arikunto, S. (2010). Prosedur Penelitian: Suatu Pendekatan Praktik (Edisi Revisi 2010 Cetakan 14) Jakarta: PT Rineka Cipta.

Ayala-Zavala, J. F., Vega-Vega, V., Rosas-Domínguez, C., Palafox-Carlos, H., Villa-Rodriguez, J. A., Siddiqui, M. W., ... \& González-Aguilar, G. A. (2011). Agro-industrial potential of exotic fruit byproducts as a source of food additives. Food Research International, 44(7), 1866-1874. https://doi.org/10.1016/j.foodres.2011.02.021

Chang, C. H., Liu, C. C., \& Tseng, P. Y. (2013). Emissions inventory for rice straw open burning in Taiwan based on burned area classification and mapping using FORMOSAT-2 satellite imagery. Aerosol Air Qual. Res, 13, 474-487.

Coolong, T. (2012). Mulches for weed management in vegetable production. Weed Control, 57-74.

Dakshene, M., Rani, A., \& Sharma, P. D. (2013). Adsorptive removal of adipic acid from their aqueous waste over alkali activated power plant fly ash. Journal of the indian chemical society, 90(4), 505-511.

Dobermann, A., \& Fairhurst, T. H. (2002). Rice straw management. Better Crops International, 16(1), 7-11.

Eusufzai, M. K., Maeda, T., \& Fujii, K. (2007). Field evaluation of compost, sawdust and rice straw biomass on soil physical and hydraulic properties. Journal of the Japanese Society of Soil Physics, 107, 3-16.

Gadde, B., Bonnet, S., Menke, C., \& Garivait, S. (2009). Air pollutant emissions from rice straw open field burning in India, Thailand and the Philippines. Environmental Pollution, 157(5), 1554-1558. https://doi.org/10.1016/j.envpol.2009.01.004

Gupta, R. (2010, December). The economic causes of crop residue burning in Western Indo-Gangetic plains. In conference held at Indian Statistical Institute, Delhi centre (pp. 1-26).

Gupta, R. (2012). Causes of emissions from agricultural residue burning in north-west India: evaluation of a technology policy response. SANDEE.

Kanokkanjana, K., \& Garivait, S. (2013). Alternative rice straw management practices to reduce field open burning in Thailand. International Journal of Environmental Science and Development, 4(2), 119. http://dx.doi.org/10.7763/IJESD.2013.V4.318

Kumari, A., Kapoor, K. K., Kundu, B. S., \& Kumari Mehta, R. (2008). Identification of organic acids produced during rice straw decomposition and their role in rock phosphate solubilization. Plant Soil and Environment, 54(2), 72.

Malhi, S. S., \& Kutcher, H. R. (2007). Small grains stubble burning and tillage effects on soil organic C and N, and aggregation in northeastern Saskatchewan. Soil and Tillage Research,94(2), 353-361. https://doi.org/10.1016/j.still.2006.08.009

Mandal, K. G., Misra, A. K., Hati, K. M., Bandyopadhyay, K. K., Ghosh, P. K., \& Mohanty, M. (2004). Rice residuemanagement options and effects on soil properties and crop productivity. Journal of Food Agriculture and Environment, 2, 224-231.

Mendoza, T. C., \& Samson, R. O. G. E. R. (1999). Strategies to avoid crop residue burning in the Philippine context. Resource Efficient Agricultural Production (REAP), Canada, 1-18.

Mustapha, S. B., Undiandeye, U. C., Sanusi, A. M., \& Bakari, S. (2012). Analysis of adoption of improved rice production technologies in Jeer local government area of Borno state, Nigeria. International Journal of Development and Sustainability, 1(3), 1112-1120.

Oladosu, Y., Rafii, M. Y., Abdullah, N., Magaji, U., Hussin, G., Ramli, A., \& Miah, G. (2016). Fermentation quality and additives: a case of rice straw silage. BioMed research international, 2016. http://dx.doi.org/10.1155/2016/7985167

Rosmiza, M. Z., Davies, W. P., Aznie, R. C., Mazdi, M., Jabil, M. J., Toren, W. W., \& Rosmawati, C. C. (2014). Farmers' participation in rice straw-utilisation in the MADA region of Kedah, Malaysia. Mediterranean Journal of Social Sciences, 5(23), 229. http://dx.doi.org/10.5901/mjss.2014.v5n23p229

Rosmiza, M. Z., Davies, W. P., CR, R. A., Mazdi, M., \& Jabil, M. J. (2017). Farmers' knowledge on potential uses of rice straw: an assessment in MADA and Sekinchan, Malaysia. Geografia-Malaysian Journal of Society and Space, 10(5). 
Sharma, K., Dhaliwal, N. S., \& Kumar, A. (2016). Analysis of adoption and constraints perceived by small paddy growers in rice production technologies in Muktsar district of Punjab State, India. Indian Research Journal of Extension Education, 15(2), 20-23.

Silalertruksa, T., \& Gheewala, S. H. (2013). A comparative LCA of rice straw utilization for fuels and fertilizer in Thailand. Bioresource technology, 150, 412-419. https://doi.org/10.1016/j.biortech.2013.09.015

Sumarno, S., Kartasasmita, U. G., \& Pasaribu, D. (2009). Pengayaan kandungan bahan organik tanah mendukung keberlanjutan sistem produksi padi sawah. Iptek Tanaman Pangan, 4(1).

Tipayarom, D., \& Oanh, N. K. (2007). Effects from open rice straw burning emission on air quality in the Bangkok Metropolitan Region. Science Asia, 33(3), 339-345. http://dx.doi.org/10.2306/scienceasia15131874.2007.33.339

Trach, N. X. (1998). The need for improved utilisation of rice straw as feed for ruminants in Vietnam: An overview. Livestock Research for Rural Development, 10(2), 1-14.

Truc, N. T. T., Sumalde, Z. M., Espaldon, M. V. O., Pacardo, E. P., Rapera, C. L., \& Palis, F. G. (2012). Farmers' awareness and factors affecting adoption of rapid composting in Mekong Delta, Vietnam and Central Luzon, Philippines. Journal of Environmental Science and Management, 15(2).

Tung Ho, L. S., \& Ané, C. (2014). A linear-time algorithm for Gaussian and non-Gaussian trait evolution models. Systematic biology, 63(3), 397-408. https://doi.org/10.1093/sysbio/syu005

Tung, S. T., Cu, N. X., \& Hai, N. X. (2014). Impact of rice straw burning methods on soil temperature and microorganism distribution in the paddy soil ecosystems. ARPN J Agric Biol Sci, 9(5), 157-160.

Wang, Y., \& McAllister, T. A. (2002). Rumen microbes, enzymes and feed digestion-a review. Asian-Aust. J. Anim. Sci, 15(11), 1659-1676. 


\section{Biography of Author}

I Nengah Muliarta, S.Si. M.Si was born January 21st, 1979 in Klungkung. He
recently stays at Perumahan Griya Bentulu Jl. Bedahulu V / A1 Denpasar. His email
is nengahmuliarta@gmail.com. Ph: 6281338576547/+6287861499449. He is now
a doctorate student at the University of Udayana, interested in The Studies
Program of Agricultural Science. He has many contributions to organizational, he
got any work experience, was written a book, got many appreciations as well
having much experience on teaching.
Email: nengahmuliarta@gmail.com

